\title{
Rootstock Effects on Growth, Cell Number, and Cell Size of 'Gala' Apples
}

\author{
Yahya K. Al-Hinai and Teryl R. Roper ${ }^{1}$ \\ Dept. of Horticulture, University of Wisconsin- Madison, Madison, WI 53706
}

AdDitional INDEX wORDs. crop load, SEM, cell number, cell size, intercellular space, flesh firmness, soluble solids concentration

\begin{abstract}
The effects of rootstock on growth of fruit cell number and size of 'Gala' apple trees (Malus domestica Borkh) were investigated over three consecutive seasons (2000-02) growing on Malling 26 (M.26), Ottawa-3, Pajam-1, and Vineland (V)-605 rootstocks at the Peninsular Agricultural Research Station near Sturgeon Bay, WI. Fruit growth as a function of cell division and expansion was monitored from full bloom until harvest using scanning electron microscopy (SEM). Cell count and cell size measurements showed that rootstock had no affect on fruit growth and final size even when crop load effects were removed. Cell division ceased about 5 to 6 weeks after full bloom (WAFB) followed by cell expansion. Fruit size was positively correlated $\left(r^{2}=0.85\right)$ with cell size, suggesting that differences in fruit size were primarily a result of changes in cell size rather than cell number or intercellular space (IS).
\end{abstract}

Size of apples is determined by a combination of cell number and size. Apple fruit size is influenced by many factors, such as thinning (Lakso et al., 1995), light interception (Robinson et al., 1983), early season temperature (Warrington et al., 1999), training system (Robinson et al., 1991), tissue mineral composition (Letham, 1961), spur characteristics (Denne, 1963a), and rootstock (Autio et al., 2003). Rootstock effects on fruit size have been inconsistent over time (Lord et al., 1985), and vary with the cultivar and across planting sites (Autio et al., 2003).

Apple fruit size is a function of cell division in early developmental stages and of cell enlargement during the remainder of the year (Westwood et al., 1967). The growth of apple buds pre-bloom has been attributed primarily to cell division, which proceeds slowly until anthesis (Smith, 1950). After pollination there is a period of rapid cell division in the young fruit that continues for $\approx 3$ to 5 weeks, or in some cases up to 12 weeks after bloom depending on the climatic conditions. Rootstock may enhance fruit size by influencing cell division, enhancing cell enlargement, producing more or proportionately more intercellular space (IS), or by a combination of these processes (Denne, 1960). Both the rate and duration of cell division are influenced by thinning either chemically or by hand (Martin et al., 1964).

Therefore, this study was initiated to determine the effect of four rootstocks on 'Gala' apple fruit growth as a function of cell number and cell size taking into account other possible sources of variability, such as tree size, crop load, seed count, canopy light interception, and fruit size.

\section{Materials and Methods}

Apple trees planted in 1994 with the same scion (TRECO Red Gala \#42) on M.26 EMLA (M.16 x M.9), Ottawa-3 (Robin x M.9), Pajam-1 (M.9 clone) and V-605-1 (M.9 open pollinated) rootstocks at the Peninsular Agricultural Research Station near Sturgeon Bay, WI. Rootstocks were randomly assigned. The soil was a Longrie sandy loam (coarse, loamy, mixed, frigid, Entic Haplorthod), $\mathrm{pH} \approx 7$ with $4 \%$ organic matter. The orchard was maintained according to $\mathrm{NC}-140$ regional research project proto-

Received for publication3 Apr. 2003. Accepted for publication 6 Oct. 2003. This research was supported by the College of Agricultural and Life Sciences through regional research funds.

${ }^{1}$ To whom requests for reprints should be addressed; e-mail trroper@wisc.edu. cols. Trees were thinned with carbaryl $\left(0.09 \mathrm{~kg} \cdot \mathrm{ha}^{-1}\right.$ a.i. $)$ after petal fall. Trees were trained to a vertical axe system. Alleys between rows were planted to a grass sod and a $2 \mathrm{~m}$ wide weed-free area within the tree row was maintained with nonresidual herbicides. The study was imposed on the same trees for 3 years.

Every year at full bloom trunk diameters of 24 trees ( 6 replications) were measured $30 \mathrm{~cm}$ above the graft union to calculate trunk cross-sectional area (TCA) as a measure of tree size. Every year at harvest the total crop load (fruit weight and number/square centimeter TCA) was calculated. Canopy light interception (1 - (PAR below canopy/PAR above canopy)) was measured during mid-July 2001 at dawn using a canopy analyzer (LAI2000; LI-COR, Lincoln, Neb.). To investigate rootstock effects on light transmission through the canopy, light measurements were collected at three different positions (base, middle, and out) on each tagged limb for three randomly selected limbs per tree and five trees per rootstock. Due to the difficulty of measuring intercepted light for each fruit, leaf samples were taken at each position along with the light measurement to use specific leaf area (SLA) as a proxy for intercepted light at fruiting locations. About fifteen fully expanded spur and shoot leaves were sampled along the limb for all trees (six replications) to calculate SLA and a regression analysis of logarithmic transformed data was used to estimate canopy light interception.

In 2000, a random sample of three mature fruit per tree was harvested from the periphery of the tree for preliminary tests. Fruit size was determined by measuring diameter, fresh weight and volume. Two cores (radial and transverse sections), were taken with a cork borer from each fruit. Cores were immediately fixed in formalin acetic acid alcohol (FAA) preservative [per $100 \mathrm{~mL}: 50$ mLethanol (95\%), $5 \mathrm{~mL}$ glacial acetic acid, $10 \mathrm{~mL}$ formalin $(37 \%$ formaldehyde), and $35 \mathrm{~mL}$ distilled water] and vacuum infiltrated for $30 \mathrm{~min}$. The cores were then sectioned longitudinally with a single sweeping stroke of a single-edged razor blade. Sections were dehydrated in a graded alcohol series, critically dried, coated with gold and prepared for scanning electron microscopy (SEM) using a scanning electron microscope (SEM S-SEM 570; Hitachi Electronics, Tokyo, Japan) operating at $5 \mathrm{kV}$.

In 2001 and 2002, weekly fruit sampling began at full bloom and at each sample date three fruit per tree and 6 trees per rootstock were harvested randomly from the periphery of the tree. Samples were prepared for SEM following the same technique used in 2000. To measure cortical cell size and calculate cortex volume 
for fruitlets sampled up to 3 WAFB, photographs for the whole fruit cross section were taken. For fruit sampled after 4 WAFB, size measurements including diameter, volume, weight, and pith diameter were recorded immediately after harvest.

Preliminary tests during 2000 showed cells of 'Gala' apples to be prolate spheroids, whose volume can be calculated by the equation: volume $(v)=4 / 3 \pi a b^{2}$, where $a=1 / 2$ the major and $b=$ $1 / 2$ the minor axis (Westwood et al., 1967). Cell size measurements were carried out by direct measurements of axis $a$ and $b$ on the SEM photographs using computer software (Adobe Photoshop 5.5). Twenty mid-cortical cells per sample were measured, excluding very small cells adjacent to vascular bundles. The number of cells in the entire cortex of a given fruit was derived from the fruit's mean values for cortex cell volume and proportion of IS, and the calculated cortex volume. Cortex cell number $=($ cortex volume $)(1.0$ - proportion IS $) \div$ cell volume. IS measurements were based on the volume of air displaced by water as a vacuum was applied above submerged tissue taken from transverse sections of midcortical region.

At harvest in 2001 and 2002, mature apple flesh firmness was determined with an Effegi penetrometer (11.1-mm-diameter probe; Effegi, Alfonsine, Italy) and SSC was measured using an Atago hand-held refractometer (Atago Co. Ltd., Tokyo, Japan) for 72 fruit ( 3 fruit/tree $\times 6$ trees/rootstock $\times 4$ rootstocks $)$. In 2000 , seeds were counted in 300 fruit along with fruit weight and volume.

Data were subjected to analysis of variance using SAS Mixed procedure and linear regression analysis of SAS Regression procedure (SAS Institute, Inc., Cary, N.C.). Regression analysis was used to examine relationships between fruit size and cell size, cell number, and intercellular space. Covariate analysis was used where it improved the efficiency of analysis. All means were separated by Fisher's protected $t$ test determined by Proc Mixed models procedure of SAS $(P \leq 0.05)$.

\section{Results}

Generally, rootstock did not affect fruit growth or size measured as the number of cortical cells through the season (Fig. 1). Cell division ceased at 6 WAFB in 2001 and at 5 WAFB in 2002. Rootstock did not affect cell enlargement rate measured as an increase in cell volume (Fig. 2); however, mature fruit from trees on Pajam-1 had slightly larger cells in 2002.

Preliminary tests during 2000 showed the cortex cell volume to differ in various regions of 'Gala' apples. However, cells in the mid-cortical tissue were representative of the mean cell volume of the cortex. Across fruit of all treatments there was a positive and significant linear relationship between fruit size and cortex volume $\left(r^{2}=0.997\right)$ calculated as a concentric sphere. Although there was a linear relationship between cell size within cortex tissue and fruit size $\left(r^{2}=0.85\right)$, cortex cell number did not affect fruit size $\left(r^{2}=0.03\right)$.

Analysis of canopy light interception data did not show a relationship between rootstock and intercepted light. Interactions between fruit size and estimated transmitted light at fruit locations $\left(r^{2}=0.012\right)$ by using SLA as a proxy for light interception $\left(r^{2}=0.63\right)$ were also not detected. Thus, light was not used as a covariate for fruit size in this experiment. The association between seed count and fruit size was not remarkable either $\left(r^{2}=0.03\right)$. However, fruit with no seeds tended to be smaller than fruit with at least one seed.

Generally, rootstock had no effect on mature fruit size, or cell size and number even with the removal of the effects of crop load by analysis of covariance (Table 1). However, in 2002, mature fruit obtained from trees on Pajam-1 tended to have larger cells when compared to Ottawa-3. Although rootstock had no effects on crop load (Table 1), fruit size was dramatically affected $(P$ $>0.0001)$.

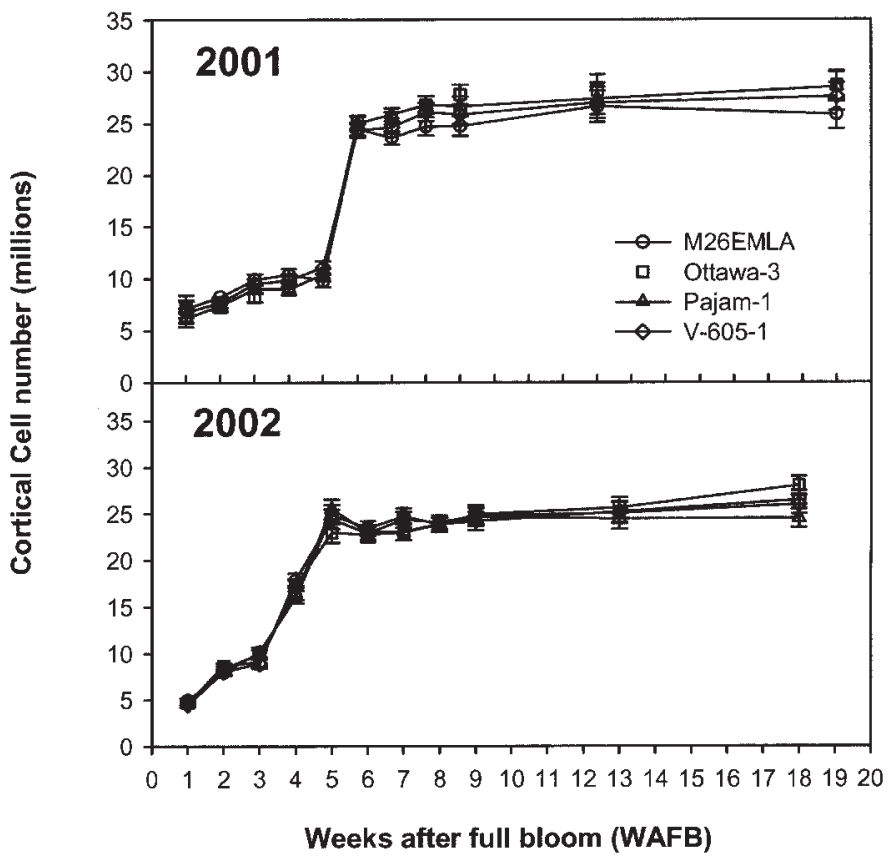

Fig. 1. Effects of four different rootstocks on 'Gala' apple fruit cortical cell number measured at weekly intervals from full bloom until harvest during 2001 and 2002 growing seasons. Full bloom was during the second week of May or first week of June in 2001 and 2002, respectively. Error bars are treatment LS means \pm SE for each sampling date, $P \leq 0.05$.

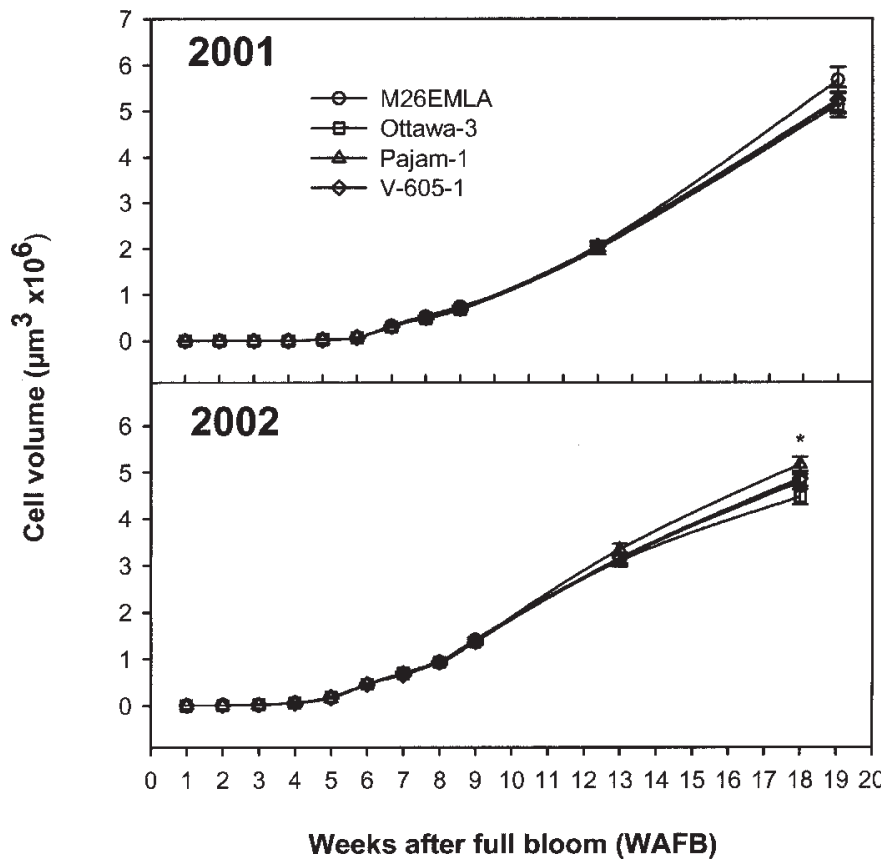

Fig. 2. Effects of four different rootstocks on 'Gala' fruit cortical cell volume $\left(\mu \mathrm{m}^{3}\right.$ $\left.\times 10^{6}\right)$ measured at weekly intervals from full bloom until harvest during 2001 and 2002 growing seasons. Full bloom was during the second week of May or first week of June in 2001 and 2002, respectively. Error bars are treatment LS means \pm SE for each measurement week, $P \leq 0.05$. *Indicates significant differences between treatments. 
Table 1. Effects of rootstock on cell volume and cell count of mature 'Gala' apples during 2001 and 2002 taking into account the influences of crop load and individual fruit volume. Scions were grown at the Peninsular Agricultural Research Station near Sturgeon Bay, Wis. $(n=4)$.

\begin{tabular}{lcccc}
\hline Rootstock & $\begin{array}{c}\text { Crop load } \\
\left(\mathrm{no} / \mathrm{cm}^{2}\right. \\
\left.\mathrm{TCA}^{\mathrm{y}}\right)\end{array}$ & $\begin{array}{c}\text { Fruit } \\
\text { vol } \\
\left(\mathrm{cm}^{3}\right)\end{array}$ & $\begin{array}{c}\text { Cell } \\
\text { vol } \\
\left(\mu \mathrm{m}^{3} 10^{6}\right)\end{array}$ & $\begin{array}{c}\text { Cell } \\
\text { no. } \\
\left(\times 10^{6}\right)\end{array}$ \\
\hline $\begin{array}{c}\text { 2001 } \\
\text { M.26 EMLA }\end{array}$ & 6.4 & 206 & 5.8 & 25.8 \\
Ottawa-3 & 7.8 & 196 & 5.1 & 28.6 \\
Pajam-1 & 7.3 & 194 & 5.2 & 28.5 \\
V-605-1 & 5.1 & 201 & 5.2 & 27.5 \\
Significance & $\mathrm{NS}$ & $\mathrm{NS}$ & $\mathrm{NS}$ & $\mathrm{NS}$ \\
2002 & & & & \\
M.26 EMLA & 9.5 & 168 & $4.8 \mathrm{ab}$ & 26.5 \\
Ottawa-3 & 10.5 & 174 & $4.5 \mathrm{~b}$ & 28.0 \\
Pajam-1 & 10.3 & 176 & $5.2 \mathrm{a}$ & 24.5 \\
V-605-1 & 10.7 & 173 & $4.9 \mathrm{ab}$ & 26.0 \\
Significance & $\mathrm{NS}$ & $\mathrm{NS}$ & $*$ & $\mathrm{NS}$ \\
\hline
\end{tabular}

${ }^{\mathrm{z}}$ Mean values with different letters within columns and years are significantly different at $P \leq 0.05$ as determined by Fisher's protected $t$ test using the Proc Mixed models procedure of SAS.

yTrunk cross-sectional area $\left(\mathrm{cm}^{2}\right)$

ss, ${ }^{*}$ Nonsignificant, and significant at $P \leq 0.05$.

Rootstock had no effect on the proportion of IS in the cortex $(P=0.39)$. This experiment did not show any relationship between IS volume and fruit volume $\left(r^{2}=0.01\right)$ nor between cell size and flesh firmness or soluble solids concentration $\left(r^{2}=0.24\right.$, 0.23 respectively).

\section{Discussion}

Generally, rootstock did not affect fruit growth and final size measured as cell number and cell size even with the removal of crop load effects probably because 'Gala' acts similarly on all tested rootstocks under Wisconsin's climatic conditions. Although some studies have shown that rootstock affects fruit size (NC-140, 1996; Autio et al., 2003), results were not consistent and varied across planting sites (Marini et al., 2000) and between cultivars (Autio et al. 2003). Rootstock, in general, might influence fruit size in some regions or with some cultivars, but this effect may not be consistent across multiple cultivars in every apple production region due to the variability in the climatic conditions such as length of growing season, seasonal radiant energy accumulation, and temperature (Stanley et al., 2000). For example, as a part of NC-140 semi-dwarf rootstock trial on 'Gala' apple, Marini et al. (2000) found that out of 24 sites in North America only 7 sites showed an interaction between rootstock and fruit size. In Wisconsin no interaction was detected. No consistent results were cited for the southern hemisphere regions either (Wünche and Palmer, 2000).

Apple fruit development occurs in three phases (Gillaspy et al. 1993). Phase I is the period before pollination including the formation of the floral meristem and flower development. Most cell division occurs in Phase II followed by cell enlargement in Phase III. In this study, the quadratic relationship between WAFB and fruit cortical cell number indicated that cell division ceases 5 to 6 weeks after full bloom in 'Gala' apples and cell expansion continues until harvest. In 'Granny Smith', cell division ceased $\approx 3$ weeks after full bloom (Bain and Robertson, 1951), 3 to 4 weeks in 'Wagener' (MacArthur and Wetmore,1941) and 'McIntosh' apple (Blanpied and Wild, 1968), 4 to 5 weeks in 'Empire' apple (Lakso and Grappadelli, 1992), 6 to 7 weeks in 'Cox's Orange Pippin'(Denne, 1963a), after $>7$ weeks in 'Dougherty' (Denne, 1963b), and 12 weeks in Miller's Seedling (Denne, 1960). The variation in the timing and the rate of apple cell division is mainly due to the variation in the climatic conditions. For example, in some cases cell division ceased at 12 weeks after bloom in cultivars grown in the southern hemisphere (Denne, 1963a) compared to 3 WAFB in North America (Blanpied and Wild, 1968).

Knowing the fruit cell division cessation time for local apple cultivars is important because it sets the critical time for thinning. Thinning was found to stimulate fruit growth by influencing the rate and duration of cell division of remaining fruit (Goffinet et al. 1995). Thus, only thinning before the cessation of cell division would be beneficial for enhancing fruit growth and size.

Variation in timing and rate of cell division between 2001 and 2002 was mainly due to the variation in daily air temperatures. Full bloom was delayed 2 weeks in 2002 because of cooler air temperatures $\left(<15^{\circ} \mathrm{C}\right)$ before bloom during May 2002 compared to the same period in 2001 . In 2002 warmer temperatures during the first 5 WAFB affected fruit growth rate by increasing the cell division rate. There was a difference of about $7^{\circ} \mathrm{C}$ between the 2 years during the first 5 WAFB, 2002 being warmer. Greybe et al. (1998) provided clear evidence that temperature during the first 6 weeks following full bloom affects the growth rate of 'Royal Gala' fruit. In contrast, Bergh's (1990) work with 'Golden Delicious', 'Granny Smith', 'Starking' and 'Starkrimson' suggests that temperature during the first $40 \mathrm{~d}$ after bloom affects not only fruit growth rate, but final fruit size as well. Although, he found that lower temperatures (below $14^{\circ} \mathrm{C}$ ) during this early period resulted in smaller fruit, this was not the case in our study. Despite the variation in timing and duration of cell division between years, no interactions between fruit size and year were evident and rootstock did not influence final fruit size any year. Hirst and Flowers (2000) documented similar results for 'Gala' in Indiana.

Apple fruit size was dramatically affected by crop load $(P<$ $0.0001)$. Many investigators have reported that heavy crop loads result in smaller fruit than light cropping (Palmer et al., 1997). The reduction in fruit size resulting from heavy cropping is related to competition for finite resources among many competing sinks. Fruit size decreased with fruit number, indicating that growth was carbon limited at high crop loads. Thus, adjusting fruit size for crop load was necessary to eliminate the variation between trees within rootstocks.

Light intercepted by the canopy has been shown to be an important determinant of fruit quality. It influences red pigmentation, soluble solids concentration, and fruit weight (Robinson et al., 1983). Marguery and Sangwan (1993) found no correlation between intercepted light and fruit anatomical characteristics such as cell number. This study showed no interaction between canopy light interception and rootstock or fruit size. Perhaps the potential reducing effect of differential light was mitigated because all trees were pruned to be relatively open to light penetration, and all fruit for anatomical analysis were harvested from the periphery of the tree. Thus, light interception was not a significant covariate.

Apple fruit size has been found to be related to seed count (Denne, 1963a). However, analysis of 300 mature fruit during the preliminary investigation in 2000 did not reveal any relationship between fruit size and seed number, suggesting 'Gala' may be partially parthenocarpic. There was no effect of rootstock on 'Gala' seed number. 
Mature fruit obtained from trees on Pajam-1 during 2002 had slightly larger cells than fruit from trees on Ottawa-3 rootstocks. Trees on Pajam-1 were found to have higher total $\mathrm{N}$ content in their leaf tissue compared to other rootstocks and this may have contributed to larger cortical cells (Al-Hinai, 2003). Westwood et al. (1967) suggested that larger cells within apple fruit might be associated with excess $\mathrm{N}$ fertilizer. The interaction between year and mature fruit cell size suggested that even if there was a rootstock effect on cell size, it was minor in 2002, observed solely at maturity and was inconsistent over time.

Fruit size is determined by the amount of cell division after pollination (Smith, 1950). In several years of study of fruit growth and thinning of 'Empire' apples, final fruit size variation was found to be primarily a result of variation in cell number rather than cell size (Lakso and Grappadelli, 1992). Our experiment suggests that differences in fruit size across rootstocks were due to cell size rather than cell number perhaps because trees were thinned very early after petal fall which took place during 1 to 2 WAFB. Cano-Medrano and Darnell (1997) showed that differences in final fruit size between pollinated and parthenocarpic blueberry (Vaccinium ashei) were due to cell enlargement rather than cell number. Although, fruit development in apples is different than in blueberries, these results suggest that other factors might be involved in these variations such as cultivars or geographic distribution. For example, Westwood et al. (1967) suggested that under Pacific Northwest conditions larger apples typically have larger cells due to greater cell expansion. However, Martin et al. (1964) working in Australia reported that larger fruit have smaller cells. Greybe et al. (1998) working on 'Royal Gala' in South Africa suggested that differences in fruit sizes were due to variation in cell number and/or cell size depending on chilling units during bud differentiation. Thus, fruit developmental differences among experiments may be due to different climatic conditions.

The contribution of intercellular space (IS) in apple fruit volume is not as well understood as cell size or number. Since middle portions of the cortex approximates the average size of all tissues of the fruit, it reflects the characteristic differences of fruit IS (Goffinet et al., 1995). Although, very little IS occurs in apple flesh during the first few weeks after full bloom, it increases greatly in size during the later stages of fruit growth and grows in constant proportion to the fruit as a whole, forming up to 23 percent of the volume of Gala's flesh tissue at harvest. Skene (1966), and Bain and Robertson (1951) found similar results for 'Cox's Orange Pippin', 'McIntosh Red' and 'Wagener', and 'Granny Smith', respectively. We did not find any relationship between IS and fruit size. This differs from the results of MacArthur and Wetmore (1941), but agrees with Goffinet et al. (1995) for 'Empire' and Hirst and Flower (2000) working on 'Gala'. Goffinet et al. (1995) showed that increases in fruit size from thinning were largely a result of increased cell numbers, with cell size and intercellular space being of minor importance. In this study, there was no interaction between IS and fruit weight or between cell number and fruit size because the size variation was likely due to fruit cell size.

We found no relationship between cell size and flesh firmness or SSC, although, it was suggested that larger fruit tend to have softer flesh due to larger cell size (Greene et al., 1990). Our results varied from Greene's perhaps because all fruit used in this study were from trees that had been thinned and thus were similar in size. Sampling different fruit sizes from different cultivars on several rootstocks might show different results.

In conclusion, rootstock did not affect fruit growth as a func- tion of cell number and cell size. Under Wisconsin's climate, thinning should be completed during the first 5 to 6 WAFB before cell division ceases. Our data suggests that differences in mature fruit sizes are primarily due to changes in cell size rather than cell number or IS when chemical thinning was used.

\section{Literature Cited}

Al-Hinai, Y.K. 2003. Rootstock effects on growth, quality, cell number and cell size of 'Gala' apple fruit. PhD diss. Univ. Wis.-Madison.

Autio, W.R., J.R. Schupp, C.G. Embree, and R.E. Moran. 2003. Early performance of 'Cortland', 'Macoun', 'McIntoch', and 'Pioneer Mac' apple trees on various rootstocks in Maine, Massachusetts, and Nova Scotia. J. Amer. Pomol. Soc. 57:7-14.

Bain, J.M., and R.N. Robertson. 1951. The physiology of growth of apple fruits. I. Cell size, cell number and fruit development. Austral. J. Sci. Res. Biol. Sci. 4:75-91.

Bergh, O. 1990. Effect of time of hand-thinning on apple fruit size. S. Afr. J. Plant Soil 7:1-10.

Blanpied, G.D. and M.H. Wild. 1968. A study of the cells in the outer flesh of developing McIntosh apple fruits. Bot. Gaz. 129:173-183.

Cano-Medrano, R. and R.L. Darnell. 1997. Cell number and cell size in parthenocarpic vs. pollinated blueberry (Vaccinium ashei) fruits. Ann. Bot. 80:419-425.

Denne, M.P. 1960. The growth of apple fruitlets and the effect of early thinning on fruit development. Ann. Bot. 24:397-406.

Denne, M.P. 1963a. Fruit development and some tree factors affecting it. N.Z. J. Bot. 1:265-294.

Denne, M.P. 1963b. A comparison between fruits of Cox's Orange Pippin from Kent, England, and Auckland, New Zealand. N.Z. J. Bot. 1: 295-300.

Gillaspy, G., H. Ben-David, and W. Gruissm. 1993. Fruits: A developmental perspective. Plant Cell 5:1439-1451.

Goffinet, M.C., T.L. Robinson, and A.N. Lakso. 1995. A comparison of 'Empire' apple fruit size and anatomy in unthinned and hand-thinned trees. J. Hort. Sci. 70:375-387.

Greene, D.W., W.R. Autio, and P. Miller. 1990. Thinning activity of Benzyladenine on several apple cultivars. J. Amer. Soc. Hort. Sci. 115:394-400.

Greybe, E., O. Bergh, and DI. Ferreira. 1998. Fruit growth and cell multiplication of 'Royal Gala' apples as a function of temperature. Appl. Plant Sci. 12:10-14.

Hirst, P.M. and R.R. Flowers. 2000. Rootstock effects on growth and cell size of 'Gala' apple fruit. Acta Hort. 517:189-194.

Lakso, A.N. and L.C. Grappadelli. 1992. Implications of pruning and training practices to carbon partitioning and fruit development in apple. Acta Hort. 322:231-240.

Lakso, A.N., L.C. Grappadelli, J. Barnard, and M.C. Goffinet. 1995. An expolinear model of the growth pattern of apple fruit. J. Hort. Sci. 70:389-397.

Letham, D.S. 1961. Influence of fertilizer treatment on apple fruit composition and physiology. I. Influence on cell size and cell number. Austral. J. Agr. Res. 12:600-611.

Lord, W.J., D.W. Greene, R.A. Damon, Jr., and J.H. Baker. 1985. Effects of stem piece and rootstock combinations on growth, leaf mineral concentrations, yield, and fruit quality of 'Empire' apple trees. J. Amer. Soc. Hort. Sci. 110:422-425.

MacArthur, M. and R.H. Wetmore. 1941. Developmental studies of the apple fruit in the varieties 'McIntosh Red' and 'Wagener' II. An analysis of development. Can. J. Res. 19:371-382.

Marguery, P. and B.S. Sangwan. 1993. Sources of variation between apple fruits within a season, and between seasons. J. Hort. Sci. 68: 309-315.

Marini, R.P, J.L. Anderson, B.H. Barritt, G.R. Brown, J. Cline, W.P. Cowgill, P.A. Domoto, D.C. Ferree, J. Garner, G.M. Greene, C. Hampson, P. Hirst, M.M. Kushad, E. Mielke, C.A. Mullins, M. Parker, R.L. Perry, J.P. Prive, G.L. Reighard, T. Robinson, C.R. Rom, T. Roper, J.R. Schupp, E. Stover, and R. Unrath. 2000. Performance of 'Gala' apple on 
four semi-dwarf rootstock: A five-year summary of the $1994 \mathrm{NC}-140$ semi-dwarf rootstock trial. J. Amer. Pomol. Soc. 52:84-91.

Martin, D., T.L. Lewis, and J. Cerny. 1964. Apple fruit cell number in relation to cropping alternation and certain treatments. Austral. J. Agr. Res. 15:905-919.

NC-140. 1996. Performance of the NC-140 cooperative apple rootstock planting: I. Survival, tree size, yield and fruit size. Fruit Var. J. 50:6-11.

Palmer, J.W., R. Giuliani, and H.M. Adams. 1997. Effect of crop load on fruiting and leaf photosynthesis of 'Braeburn'/M.26 apple trees. Tree Physiol. 17:741-746.

Robinson, T.L., A.N. Lakso, and S.G. Carpenter. 1991. Canopy development, yield, and fruit quality of 'Empire' and 'Delicious' apple trees grown in four orchard production systems for ten years. J. Amer. Soc. Hort. Sci. 116:179-187.

Robinson, T.L., E.J. Seeley, and B.H. Barritt. 1983. Effect of light environment and spur age on 'Delicious' apple fruit size and quality. J. Amer. Soc. Hort. Sci. 108:855-861.
Skene, D.S. 1966. The distribution of growth and cell division in the fruit of 'Cox's Orange Pippin'. Ann. Bot. 30:493-512.

Smith, W.H. 1950. Cell multiplication and cell enlargement in the development of the flesh of the apple fruit. Ann. Bot. 53:23-38.

Stanley, C.J., D.S. Tustin, G.B. Lupton, S. McArtney, W.M. Cashmore, and H.N. DeSilva. 2000. Towards understanding the role of temperature in apple fruit growth responses in three geographical regions within New Zealand. J. Hort. Sci. Biotechnol. 75:413-422.

Warrington, I.J., T.A. Fulton, E.A. Halligan, and H.N. De Silva. 1999. Apple fruit growth and maturity are affected by early season temperatures. J. Amer. Soc. Hort. Sci. 124:468-477.

Westwood, M.N., L.P. Batjer, and H.D. Billingsley. 1967. Cell size, cell number, and fruit density of apples as related to fruit size, position in cluster, and thinning method. Proc. Amer. Soc. Hort. Sci. 91:51-62.

Wünsche, J.N. and J.W. Palmer. 2000. Effects of crop load on fruiting and gas-exchange characteristics of 'Braeburn'/M.26 apple tree at full canopy. J. Amer. Soc. Hort. Sci. 125:93-99. 